\title{
Despite the Valuev Directive: Books Permitted by the Censors in Violation of the Restrictions Against Ukrainian Publishing, 1864-1904
}

\author{
Johannes Remy \\ University of Helsinki
}

\begin{abstract}
In 1863, the Russian imperial government decreed restrictions on book publishing in Ukrainian. The restrictions were then revised and were endorsed on several later occasions. They banned nonfiction literature directed at common people, children's literature, and translations from Russian. The restrictions were in force until the all-Russian revolution in 1905, although they were formally repealed only in 1907. This article discusses the books the censors authorized for publication despite the fact that their publication violated the restrictions on Ukrainian publishing. In the years 1863-1904, 125 such books were published in all. Most of them appeared during three periods: 1874-76, 1882-83 and 1896-1904. In the first period, most books were permitted by a corrupt censor in Kyiv who received bribes from the local Hromada, a Ukrainian society. In the second period, minor concessions to Ukrainian publishers were deemed politically expedient. In the third period, the censors took the general usefulness of the book into account; if they deemed the book useful, they permitted it even though its publication violated the restrictions. Ukrainian activists used these opportunities because they facilitated popular enlightenment in the Ukrainian national spirit through book publishing.
\end{abstract}

Keywords: Russian Empire, Ukraine, censorship, popular enlightenment, nonfiction, book history.

$\mathrm{T}$ he topic of this article is the literature that censors authorized for publication in violation of the Valuev Directive, the Ems Ukaz, and other acts that restricted the scope of Ukrainian literature in the Russian Empire. A detailed description of the most important books published in the 1870s and bibliographic information for the later period is offered. What was impermissible varied over time. The Valuev Directive of 1863 banned all literature directed to readers among the common people (Miller 263-66). ${ }^{1}$ Within this category of books, the Directive specified nonfiction as impermissible. However, its wording was somewhat ambiguous concerning the nonfiction published for the educated classes of society. The Ems Decree of 1876 removed all ambiguity by banning all nonfiction except historical

\footnotetext{
${ }^{1}$ Full text of the Valuev Directive in the original Russian and in English translation; see also Moser's and Shandra's articles in this issue.
} 
documents (Miller 267-73). ${ }^{2}$ It also added a ban on texts published with musical notes. In 1881, musical texts and dictionaries were permitted again (Boriak 188-91). ${ }^{3}$ However, a ban on all translations from Russian into Ukrainian was added in 1892 (Boriak 247), ${ }^{4}$ and children's literature was forbidden three years later (Boriak 294-95, 301-02, 310-11). ${ }^{5}$ Finally, the revolution of 1905 removed the restrictions, although they were formally repealed only in 1907.

The censors did not always act according to the letter of the administrative acts that contained the restrictions on Ukrainian literature. The governmental prohibition of Ukrainian literature was not limited to nonfiction, translations from Russian, and children's literature. Sometimes the censors deemed all Ukrainian literature to be harmful and acted on the basis of this judgement. In the years 1868 and 1879, only one Ukrainian book per year was published (Omel'chuk et al. 1: 56-58, 106-10). In 1865-69 only ten and in 1877-80 twenty books in Ukrainian were published (Omel'chuk et al. 1: 50-60, 97-114). ${ }^{6}$ Because both before and after these periods, many more books in Ukrainian appeared, censorship is the most probable explanation of these anomalies. In 1875, the Kyiv censor Il'ia Puzyrevskii wrote to Main Administration of Press, claiming that he had prevented the publication of several works in Ukrainian (RGIA f. 776, op. 11, 1872g., delo 80, l. 97; Remy 107). ${ }^{7}$ To be sure, Puzyrevskii, who was bribed by the Kyiv Hromada and needed to defend his tolerant policies regarding Ukrainian publications, is not necessarily a reliable source. However, it is a revealing fact that he found it necessary to emphasize to his superiors how he obstructed publication of all Ukrainian books, not only those that were banned in the Valuev directive. Furthermore, we do not have to rely on Puzyrevskii's testimony only. Sometimes, even works that did not contain politically sensitive passages were banned, because they were in Ukrainian. To name one such case, in 1883, Main Administration of Press banned Panteleimon Kulish's translations of Shakespeare's works (Boriak 199). ${ }^{8}$

\footnotetext{
2 The Ems Ukaz in its original Russian and in English translation; see also Bilenky.

${ }^{3}$ Nikolai Pavlovich Ignat'ev's memorandum endorsed by Alexander III, 3 October 1881.

${ }^{4}$ Main Administration of Press to Kyiv censor, 10 January 1892.

5 I have not been able to locate the directive that banned children's literature. However, this directive, dated 2 December 1895, is referred to in the context of several later decisions made by censors.

${ }^{6}$ See Bilenky. Nikolai Fabrikant (aka Ivan Krevets'kyi) was wrong when claiming that in the first decade after the Valuev Directive, only one Ukrainian book was published. ${ }^{7}$ In RGIA, in Puzyrevskii's report on his activities in the year 1874.

${ }^{8}$ Main Administration of Press to the Kyiv censor of foreign literature, 9 December 1883.
} 
Since Russian translations from Shakespeare were permitted, the decision was based on the language of Kulish's translations, not their contents. In 1892, Main Administration instructed the Kyiv censor to reduce the number of Ukrainian publications "as much as possible on the basis of slightest excuses" (Boriak 247; Saunders, "Russia's Ukrainian Policy," 181, 202; Rodkiewicz 210). ${ }^{9}$

Deviations from the letter of the restrictions occurred in the other direction, too: works that were clearly banned in the Valuev Directive and the Ems Ukaz were authorized for publication. In all, 125 such books were published from 1864-1904. These deviations occurred mainly in three periods: 1874-76, 1882-83, and 1896-1904. The number of books permitted in violation of restrictions against Ukrainian publishing, 1864-1904 (compiled on the basis of Omel'chuk et al.), is presented in the following table.

$\begin{array}{ll}1866 & 1 \\ 1870 & 1 \\ 1871 & 1 \\ 1873 & 1 \\ 1874 & 7 \\ 1875 & 5 \\ 1876 & 7 \\ 1880 & 1 \\ 1881 & 1 \\ 1882 & 5 \\ 1883 & 9 \\ 1884 & 1 \\ 1894 & 1 \\ 1895 & 1 \\ 1896 & 5 \\ 1897 & 6 \\ 1898 & 4 \\ 1899 & 9 \\ 1900 & 7 \\ 1901 & 16 \\ 1902 & 14 \\ 1903 & 10 \\ 1904 & 12\end{array}$

In a previous publication, I analyzed the reasons for the violations of the

\footnotetext{
${ }^{9}$ In Boriak, Main Administration of Press to the Kyiv censor, 10 January 1892; see also Bilenky for cases where works of Ukrainian fiction were banned on grounds that were not mentioned in either the Valuev Directive or the Ems Ukaz. All translations are my own.
} 
Valuev Directive in the years 1874-76 (Remy 101-10). Eighteen of the nineteen books published in violation of the Valuev Directive in this period appeared in Kyiv. Because of the bribes he received from the Kyiv Hromada, the Kyiv censor Puzyrevskii permitted nonfiction directed at common people. He was able to do this because Governor-General Aleksandr Mikhailovich Dondukov-Korsakov practiced a benevolent policy towards Ukrainian national activists. Puzyrevskii's lenience alarmed Main Administration of Press which dismissed him after having received evidence of his corruption. The nineteen books published in violation of the Valuev directive in 1874-76 concerned the following topics:

$\begin{array}{ll}\text { Natural science } & 6 \\ \text { History } & 4 \\ \text { Medicine } & 3 \\ \text { Law } & 2 \\ \text { Theology } & 1 \\ \text { Biography (Hans Christian Andersen) } & 1 \\ \text { Economics } & 1 \\ \text { Dictionary } & 1\end{array}$

All these books, except Mykhailo Levchenko's Opyt russko-ukrainskogo slovaria (Attempt at a Russian-Ukrainian Dictionary), ${ }^{10}$ were clearly intended for readers among the common people: the contents were elementary and readers were presumed to have no prior knowledge of the topics discussed. The great share of natural science was a consequence of the popularity of positivism in the Kyiv Hromada. Aleksei Miller has perceived an analogy between the political strategies of the Kyiv Hromada and Polish Warsaw positivists in the 1870s: both groups tried to use all available opportunities for lawful national work and to avoid conflicts with the imperial government (160-61). Miller's analogy can be expanded: the Hromada's positivist outlook was also visible in its emphasis on natural science and practical knowledge. While national romanticism was present in the Hromada, it was now less prominent than it had been before the enactment of the Valuev Directive in 1863.

One of the most ambitious books on natural science was the third edition of De-shcho pro svit Bozhyi (Something About God's World), a collective work of the Kyiv Hromada that was originally published in 1861. It was more than one evening's reading: the 1874 edition had 101 pages. Something About God's World discussed earth and its round form, causes of the alternation of day and night and seasons of the year, gravitation, the solar system and stars, heat, water, and precipitation, air, atmosphere, different climates on various parts of the earth, and the alternation of weather. The only hint of Ukrainian

10 See Moser. 
nationalism was an epigraph from Taras Shevchenko who called his countrymen to study. However, the long foreword on the usefulness of literacy conveyed messages that inform us about the ideological outlook of the authors. It presents the history of humankind as a gradual progress with knowledge as the moving force. According to the foreword, the main difference between human beings and animals is not intelligence, but language, which enables us to increase our knowledge and skills. Literacy has further increased our capacity to transmit information and learn from it. At first, human beings lived in forests like wild animals, with no knowledge of God, laws, good and evil. Gradually, they learned agriculture and cattle raising. The foreword contrasts the lives of ancient wild people with the present situation: now, everyone eats better and is protected from cold and heat by clothes and houses. Today's people have Christian faith and laws, the purpose of which is to protect everyone from wrongdoing. All this human beings invented with "their own intelligence, language, literacy and science" (De-shcho 8). ${ }^{11}$ Only by reading, can one learn the basics of Christian faith. Without literacy, it happens that people call themselves Christians, attend church services on all feasts' days, observe all church rules, but "live worse than Jews" (De-shcho 9).

An additional benefit of literacy is that it enables us to read laws without relying on others. People ignorant of the law are often wronged, and they end up paying in situations in which it is not necessary. Books tell us how to increase agricultural production and how to protect one's health. Because of all these reasons, it is a good idea to spend Sundays after liturgy in reading; the literate will read to the illiterate, and both will gain wisdom. All children aged six to fourteen, including girls, should attend school. In several passages, the authors warn readers about half-educated teachers, like deacons, retired soldiers, and village scribes, who produce more harm than good. Instead, they recommend learned friends of people who were "always concerned in how to help the poor" (De-shcho 10). Despite the references to and even the emphasis on Christianity, the authors of Something About God's World refuted many popular religious beliefs, like that the stars were windows to paradise opened by the angels. After the foreword, the text is strictly scientific and God is no more mentioned. ${ }^{12}$

Other natural science books of the 1870s did not contain ideological messages as explicit as those in Something About God's World. Shcho robyt'sia $u$ vozdusi i shcho z toho treba znaty zemlerobu (What Happens in Air and What an Agriculturalist Needs to Know About It) is a Ukrainian translation from N. Gorbunov's Russian work that retains the original frame of reference, Russia.

\footnotetext{
${ }^{11}$ My references are to the second, 1863, edition, since it is the only one that has been available to me.

12 See Moser's article in this volume.
} 
Different climates are explained with examples taken from everywhere in the empire. To be sure, the anonymous translator invents a Ukrainian word for thermometer: teplomir. Other translations from Russian included A. Ivanov's Rozmova pro nebo ta zemliu (Conversation About the Sky and the Earth), ${ }^{13}$ an astronomy book, and the same author's Rozmova pro zemni syly (Conversation About the Earthly Forces), an introduction to physics. In these books lessons in science are bound together in a fictional story about a peasant boy San'ko, who begins to wonder about the form of the earth and gradually learns more by using his own wits, and by presenting questions to the priest and the landlord's son, as well as by doing experiments. Other boys ridicule San'ko. However, San'ko gets his reward when the landlord's son takes him to town to attend school. Returning home on holidays, San'ko stuns his fellow villagers with his lessons in physics. He teaches his own father, among others, refuting the latter's skepticism by demonstrating a simple scientific experiment. Thus, knowledge reverses the traditional family hierarchy. Ivanov's books included more than a hint of the opportunity of upward social mobility through education and informed readers about secondary school and university: "in these two schools one has to study eleven years. As you see, in such a long period even a fool becomes wise" (Rozmova pro nebo ta zemliu 23). San'ko's curiosity extends to the possibility of extraterrestrial life, but the young lord leaves this question unsolved: "'So, are there people only on earth?' 'I do not know that, brother. Perhaps on some planets or stars there is air and people live there. However, I know for certain that there is no air on the moon"' (Ivanov, Rozmova pro nebo ta zemliu 40). Mykhailo Komarov adapted his translation to Ukrainian conditions and added a scene with the singing of folk songs about Cossacks. He also proposed some interesting neologisms, like dalekohliad for telescope. However, these books did not contain any explicit nationalism.

Fedir Vovk's Vedmedi (Bears) was the first piece of light nonfiction in Ukrainian. Although it explained the bear's place in the classification of mammalian species, most of the book consisted of exciting stories about both wild and tamed bears and bear hunting.

Stepan Nis, a professional physician and active participant in the national movement, wrote all of the three books on medicine that were published, thanks to Puzyrevskii's corruption. Nis's approach to folk healing was remarkable, for he took it seriously. His books were based on both scholarly medicine and popular healing practices. Nis's nationalism may have impacted his attitude to folk healing, as the title of his book Liky svoienarodni, z domashnieho obikhodu i v kartynakh zhyttia (Folk Cures, Used

${ }^{13}$ A reprint of this book was banned in the beginning of the 1900s. See Bilenky. 
at Home. Accompanied by Scenes of Life) indicates; for him, folk healing was Ukrainian healing. Nis wrote in his Pro khvoroby (On Diseases) that the enlighteners of people must take into account the common people's knowledge and base their efforts on it. Accordingly, much of Nis's medical advice is based on folk practices: for instance, if you suffer from furuncle, place a frog on it! Nis's nationalism was also evident in that in the context of treating wounds, he added a short discussion on Cossack history and quotations from historical folk songs. To be sure, Nis did not approve of all folk healing habits. His Pro kholeru (On Cholera) was entirely based on scholarly medicine. Nis gave his readers the advice to avoid contaminated drinking water and to pay attention to the purity of water in general. However, this advice, which today is known to be the most important, came only as one among many others, like avoiding contaminated air.

Not surprisingly, Ukrainian nationalism was most explicit in historiography. Ivan Nechui-Levyts'kyi published three titles that discussed the earliest period of medieval Rus', Tatar and Lithuanian periods, and the Brest Union of 1596. In Pershi kyivs'ki kniazi (First Kyivan Princes) Nechui uses the terms "Ukraine" and "Ukrainian language" for the country and its language in the early Kyiv period of Rus'. He informs readers about the mixed "Finnish" [Finno-Ugrian] Slavic origins of the Great Russians. Nechui also writes that "Rus'" was the original name of Ukraine. The name "Ukraine" was adopted after the Great Russians established "Russia" as the name of their country. Nechui displays antipathy towards Poles and writes about "Catholics" as being representatives of an alien faith even before the separation of the Latin and Greek churches in 1054. He emphasizes how in the early Kyiv period peasants held their land in common and performed no labour obligations to anyone. He accepts the Norman theory of the origins of the first Kyiv princes and their retinues, explaining to readers that Norsemen came from beyond the Baltic Sea, on the coast of which St. Petersburg is located, and that they were similar to Germans. According to Nechui, Ukrainians were laborious and peaceful, whereas Norsemen were warlike. Nechui's Tatary i Lytva na Ukraini (Tatars and Lithuanians in Ukraine) was remarkable for its adoption of Lithuania into Ukrainian history. According to Nechui, Belarusians are Ukrainians who merely pronounce words in a somewhat different way. This viewpoint makes it easy for him to emphasize the Ukrainian impact on Lithuania: according to Nechui, all of Grand Prince Olgerd's [Algirdas's] sons converted to Orthodoxy and "became fully Ukrainians" (Levyts'kyi, Tatary i Lytva 36). Accordingly, Vitovt [Vytautas] was a Ukrainian Grand Prince. Nechui rendered Vitovt's title as "Grand Prince of Lithuania and Ukraine" (Levyts'kyi, Tatary i Lytva 39). Naturally, Nechui evaluates Lithuanian rule rather positively. To be sure, he criticizes Vitovt in that he was a Catholic and too friendly with Poles. In Uniia i Petro Mohyla-kyivs'kyi mytropolyt (Church Union and Petro Mohyla the Kyiv 
Metropolitan) Nechui sides with the Orthodox Church against the Greek Catholics in communion with Rome. He perceives the Brest Union of 1596 as part of the Polish campaign to denationalize Ukrainians, claiming that Poles set as their goal the destruction of not only the Orthodox Church, but also the Ukrainian language. Likewise, Petro Mohyla and his Academy promoted church literature "in our language," by implication, Ukrainian (Levyts'kyi, Uniia 38). Nechui evaluates the Polish domination in Ukraine as the worst and most oppressive period of Ukrainian history. He even calls the Uniates "enemies of the Ukrainian people" (Levyts'kyi, Uniia 26). Nechui's book sent a strong political message, since it was published at the time when the imperial government was organizing an official conversion of the Greek Catholics of the Kingdom of Poland to Orthodoxy. In other words, he sided with the imperial religious policy regarding the Uniates. To be sure, he did not explicitly discuss contemporary events.

Mykhailo Drahomanov's Pro ukrains'kykh kozakiv, tatar ta turkiv (On Ukrainian Cossacks, Tatars, and Turks) was a condensed history of the Cossack period with a short introduction that discussed earlier periods. Drahomanov portrayed Turks and Crimean Tatars as the most formidable enemies of Ukrainians, but he also inserted a defence of religious tolerance:

\begin{abstract}
Muslims consider this faith the only correct one, and they find all other faiths bad, impure. Muslims command [the faithful] to wage war against people of other faiths and forcibly convert them to their own faith. Once, all Christians, too, thought in the same manner like Muslims about their own and other faiths, and that is why both waged war and murdered each other for centuries. One did not live in peace, work for economy and learning, and trade with others what one had produced and learned. No, we had to fight with the other only because he did not think like we, and forcibly convert him from one faith to another. Thus Christians got enraged against Muslims, and Muslims against Christians. (178)
\end{abstract}

Drahomanov's short description of the events in Pereiaslav in 1654 presented them as a Cossack decision to submit themselves to the tsar, and he did not mention any Russian-Ukrainian negotiations in this context. However, he made it clear that after the agreement, the imperial policies and Cossack wishes had often diverged from each other. Furthermore, he described Ukrainian people and their history as essentially separate from Russians, Muscovy, and the Russian empire. In Drahomanov's text, Russia was merely one power that contested for suzerainty in Ukraine, others being Poland and Turkey.

In addition to these works, Puzyrevskii permitted two other works which explained the judicial and conscription reforms: Mykola Trots'kyi, Iak teper odbuvatymet'sia voienna sluzhba (How Military Service Is to Be Served from Now on) and anonymous Pro kary, do iakykh prysudzhuiut' myrovi suddi 
(On Punishments Used by Justices of Peace $)^{14}$. As nonfiction directed at common people they clearly violated the Valuev Directive. The book on Justices of Peace explains their prerogatives and procedure. Its anonymous author clarifies the difference between a criminal act and a less serious transgression, but otherwise does not include more general ideas. Trots'kyi's book on conscription is explicitly written in order to disperse various groundless rumours about the military reform, for example, that [Ukrainian] Cossack regiments are to be re-established, or that women are also to be conscripted. In the new conscription system, the educated served for a shorter period than the illiterates, and even elementary education led to substantial benefits in this field. That gives the author an opportunity to discuss elementary education in general. He argues against elementary education in Russian or Old Slavonic, disapproving of teachers who fool their pupils so that they are no more able to understand their own language. Trots'kyi recommends that village communities take more active participation in elementary schools, including the selection of teachers. The communities should request zemstvos, regional elected assemblies, to pay more attention to elementary schooling. The author's recommendation implies a preference of zemstvo schools over Orthodox Church schools, for these two agencies competed with each other in organizing elementary education. Trots'kyi advises especially against nominating "drunk deacons" as teachers, since they do not understand anything about instruction (29).

Vikhtur Shcherbatyi's (a pseudonym) Pro hroshi (On Money) was a translation from Russian, although the translator did not give the title and author of the original work. Ukrainian nationalism was visible in a quotation from Shevchenko about the importance of studies, the same verses that were quoted on the cover of Something About God's World. The topic and contents of the book were politically sensitive. Although the author discusses calmly the role of money in the economy, his or her socialist, and possibly Marxist, sympathies are patent. For the author, money is only a means of exchange, and he or she emphasizes how it does not produce anything or have any value separate from goods which can be bought for it. The value of money is derived from products that are produced by labour. Only labour creates economic value, although money is useful, for it facilitates easy exchange of goods with others. The author claims that the value of goods is defined by the labour that is spent in their production. He or she gives boots as an example: a pair of lord's boots costs three times more than boots that are made for common people, because the shoemaker works three times more for a pair of lord's shoes. If one peasant finds money by chance and ceases working, his community loses wealth instead of gaining it, for now they have

14 Puzyrevskii authorized the manuscript for publication in November 1875. 
to feed a person who does not work. The author disapproves of a system in which some people are exempt from work, but is cautious enough not to use the word "capitalism." To be sure, he or she acknowledges that supply and demand have impact on prices, but finds this situation undesirable, since it facilitates the monopolistic manipulation of prices, for which he or she accuses "Jews" (Pro hroshi 13) ${ }^{15}$ Furthermore, the author finds the common people's access to goods more important than the aggregation of accumulated wealth. Even when there is very much wealth in a society, the lower classes do not profit from it, if the rich have an opportunity to oppress the poor. According to On Money, the more self-sufficient a village community is, the better. Peasants should establish factories that function only in winter, when there is not much work in agriculture. Workers should divide the profit among themselves. This would bring to villages locally produced goods and do away with the high prices connected with cargo expenses and the transport business in general. The book informs readers about the workers' credit unions in Germany and peasant credit unions in Russia and Ukraine, recommending the establishment of such credit unions in all villages. Peasant deputies should propose that zemstvos allocate funds to credit unions. Although On Money does not criticize the government or instigate readers to any illegal activities, its economic message certainly is hostile to the order that prevailed at the time of publication.

In 1874, the censors in Holy Synod committed an additional violation of the Valuev Directive by permitting a second edition of Father Stepan Opatovych's Biblical history. The book did not contain any political ideas. However, the fact that it was published is remarkable, since the Valuev Directive was especially strict against religious literature in Ukrainian.

The second period with many violations of the restrictions against Ukrainian literature was 1882-83. It followed immediately after the reform of October 1881, by which certain modest concessions were made to Ukrainian publishing: it was now possible to publish dictionaries and lyrics with music, which were both forbidden in the Ems Ukaz of 1876. Furthermore, staging of plays in Ukrainian was permitted, and this implicitly led to permission of such plays in print. However, in two years, fourteen titles were published that should have been forbidden even with the new, softened rules. This time, the cause of permitting Ukrainian nonfiction must be sought in the central administration of censorship in the Russian Empire: according to the Ems Ukaz, local censors were not allowed to permit any literature in Ukrainian, and they had to refer it to Main Administration of Press in St. Petersburg.

\footnotetext{
15 This anti-Semitic generalization leads me to guess that the translator Shcherbatyi may be Serhii Podolyns'kyi, who in these years published similar illegal books that explained socialist ideas to common people.
} 
Why did Main Administration of Press relax censorship somewhat more than was explicitly permitted in October 1881 ? The discussion that preceded the softening of the Ems Ukaz offers a clue to this question. In January 1881, the Governor-General of Kyiv Mikhail Ivanovich Chertkov recommended a repeal of all restrictions against Ukrainian publishing (Boriak 171-73). ${ }^{16}$ Later in the same month, Dondukov-Korsakov, who was now the governorgeneral of Kharkiv, made a similar proposal, although he wanted to retain the ban on Ukrainian orthography, kulishivka (Boriak 173-180). ${ }^{17}$ In February, these proposals were countered by Senator Aleksandr Aleksandrovich Polovtsov's opinion that no explicit changes should be made, but that "one-time permissions should be granted in multitude for concerts, publications, etc., in short, for all irrelevant activities ( $n a$ vsiu igrushechnuiu chast')" (Boriak 181). ${ }^{18}$ Although none of these dignitaries became members of the Special Committee who wrote and submitted to Alexander III the final proposal of the modest concessions regarding Ukrainian publications, their opinions were certainly known to the head of Main Administration of Press, Prince Pavel Petrovich Viazemskii. It is possible that Polovtsov's opinion about unofficially relaxing censorship without repealing the Ems Ukaz had some resonance in Main Administration.

What were the books thus permitted? They were not irrelevant. The fourteen books had the following topics: natural science 3, general elementary textbooks 2 , contemporary events 1 , medicine 1 , bibliography 1 , geography 5 , religious songs 1 . For popular education, the fourth edition of Something About God's World, Borys Hrinchenko's work on thunder and lightning, and Oleksandr Konys'kyi's primer were important: Konys'kyi's was the first Ukrainian primer published since 1862, and the only one in the period 1864-1904. After the primer, readers were able to advance to Tymofii Lubenets"s work Chytanka: Persha knyzhka pislia hramatky: Z 60 maliunkamy (Reader: The First Book After Primer, with 60 Images). Apart from lessons, the book contained Ukrainian poetry, including works by Shevchenko, Leonid Hlibov, Ievhen Hrebinka, Konys'kyi, and others. O. F. Komarov's book discussed insects from an economic viewpoint (Stepovyk, Opovidannia pro komakh). The book was of impressive length, 250 pages; thus it may well have been aimed at noble landowners and other educated

16 Chertkov to Minister of Internal Affairs Mikhail Tarielovich Loris-Melikov, not before 12 January 1881.

17 Dondukov-Korsakov's memorandum to the Ministry of Internal Affairs, 31 January 1881.

18 The quoted expression on page 181. Polovtsov to Deputy Minister of Internal Affairs Mikhail Semenovich Kakhanov; see also Bilenky. Ivan Krevets'ky claimed that the short period of relaxed censorship in the beginning of the 1880 s was also a consequence of corruption. 
readers. ${ }^{19}$ M. F. Khvidorovs'kyi was able to publish a popular medical guidebook about diphtheria. Politically, it was more remarkable that Danylo Mordovets' was permitted to respond in Ukrainian to Kulish's work Krashanka rusynam i poliakam na Velykden' 1882 roku (Easter Egg to Rusyns and Poles on Easter 1882), which was published in Austrian Galicia. Mordovets"s Za krashanku - pysanka P. Ol. Kulishevi (Easter Egg for an Easter Egg to Panteleimon Kulish) (Beliaiev 26; Nakhlik 1: 374, 376) ${ }^{20}$ explicitly discussed contemporary politics and controversial questions of Ukrainian history. It is not difficult to understand the reason for this exception to censorship rules. In his work, Kulish supported reconciliation between Galician Rusyns and Poles, while Mordovets' was opposed to such reconciliation. Mordovets' criticized Kulish for a disrespectful attitude to historical Cossack heroes and Shevchenko, and for an excessively positive perception of the role of Polish nobility in Ukrainian history. Since the imperial government was hostile to Polish and Ukrainian nationalisms, the censors deemed it expedient to permit a book that presented an opinion against an alliance of these two movements. Mykhailo Komarov's bibliography summed up the achievements of literature in modern Ukrainian since Kotliarevs'kyi. K. Hamaliia published the series Zemlia i liude $v$ Rossii (Land and People in Russia) in six books, the last of which appeared in 1884. They covered the Arctic, northwest Russia including St. Petersburg, the forest zone, and the Caucasus. Most likely, the rationale behind the permission of Hamaliia's series was that it contained information about the empire and was deemed to promote identification with it. However, Hamaliia's Kavkaz (Caucasus) was the last book to appear in the 1880s in violation of the Ems Ukaz. In April 1884, Hamaliia was informed that "further publications of this kind of brochures will not be permitted" (Boriak 204). ${ }^{21}$ The next exception to the Ems Ukaz took place only in 1894.

The last period, 1896-1904, with many exceptions to the Ems Ukaz, was the longest, and it ended in the revolution of 1905 and the subsequent repeal of restrictions against Ukrainian publishing. Also, in the quantity of exceptions, this period was the most important one: 83 books were published which, according to the Ems Ukaz, should have been banned. Indeed, the restrictions gradually eroded before they were repealed, although their impact continued right up to the revolution. The most "permissive" year was 1901, when sixteen works were permitted in violation of the restrictions. The publications permitted in this period, despite the restrictions, had the following topics (Omel'chuk, et al., vols. 2-

\footnotetext{
${ }^{19}$ See Bilenky. A reprint of this book was banned in 1901.

${ }^{20}$ Slipchenko-Mordovets" work has not been available to me. I write on the basis of Ievhen Nakhlik and V. H. Beliaev.

${ }^{21}$ Main Administration of Press to the Kyiv censor, 5 April 1884.
} 
3):

$\begin{array}{ll}\text { Agriculture, cattle raising, veterinary science } & 19 \\ \text { Technology, applied natural science } & 3 \\ \text { Fairy tales, children's literature } & 7 \\ \text { Ethics, practical guidebooks about good life } & 10 \\ \text { Religion } & 1 \\ \text { History, biography } & 21 \\ \text { Medicine } & 13 \\ \text { Biology } & 3 \\ \text { Economy } & 2 \\ \text { Translations of fiction from Russian } & 2\end{array}$

David Saunders has written about one of the first exceptions granted in this period ("The Russian Imperial Authorities," 417-28), Ievhen Chykalenko's Rozmovy pro sel's'ke khoziaistvo (Conversations About Farming). ${ }^{22}$ After permission to publish the book was rejected, Chykalenko did not give up, insisting in its innocuousness and usefulness, and the censors yielded. They were convinced especially by the book's practical usefulness. Chykalenko thought that his connections in the imperial administration may have helped in the final outcome. If they helped, they left no traces in the official documents. However, Chykalenko's work was not the first practical guidebook to pass censorship. Witold Rodkiewicz has written about the general tendency towards a relaxation of restrictions after 1895 (211). In the preceding year, 1896, S. Vahanov's book on cattle diseases and Mariia Hrinchenko's (pseudonym Zahyrnia) work on steam engines on railways (Iak vyhadano) were published. In 1897, Mariia Hrinchenko's popular historical work on Jeanne D'Arc was permitted (Orleans'ka divchyna). Clearly, Main Administration of Press was now moving to a more practical attitude: the perceived usefulness of a book became relevant to its permission. In July 1898, Main Administration of Press decided to permit useful guidebooks in agriculture and medicine (Boriak 283-84). ${ }^{23}$ The decision was immediately interpreted in a somewhat broader sense: Fadei Ryl's'kyi's book on work opportunities in Kherson and Oleksandr Komarov's work on bats, hedgehogs, and moles (Stepovyk, Korystni zviriatka; Boriak 290-91) ${ }^{24}$ were permitted. The relaxation of the rules advanced, and the first works on Ukrainian history appeared in 1901. They included publications on Cossack history and Konys'kyi's stories about Shevchenko (Komar, Opovidannia pro Antona, Opovidannia pro Bohdana; Konys'kyi, Opovidannia;

\footnotetext{
22 Subsequently, Chykalenko's book was reprinted in several additional editions.

23 Decision of Main Administration of Press, 21 July 1898.

${ }^{24}$ Main Administration's decision, 24 February 1899.
} 
Kulish, Khmel'nyshchyna; Vyhovshchyna). ${ }^{25}$ The Ems Ukaz did not lose its relevance, but it was interpreted in a more narrow sense than previously. It was applied especially to books that contained nationalist ideas, works translated from Russian, primers and other books that could be used in instruction, children's literature, and books that deviated from Russian orthography. No primers at all were permitted, and textbooks for children were not permitted even in the first years of the 20th century (Boriak 29495, 301-02, 310-11). ${ }^{26}$ However, it is not easy to discern a consistent pattern in what was rejected and what was not. For instance, although Mariia Hrinchenko's book on Jeanne D'Arc was published, her biography of Abraham Lincoln was rejected (Boriak 273, 275, 286, 288). ${ }^{27}$ In September 1902, a fifth edition of Something About God's World was rejected (Boriak 309). ${ }^{28}$ It was not an immediately useful practical guidebook, since it did not provide advice on how to apply the knowledge in physics and astronomy. However, the books on Ukrainian history that were published at the same time were hardly more practical. In the field of history, mainly popularizations rather than research literature appeared until 1904, when the Academy of Sciences published two of Mykhailo Hrushevs'kyi's articles in separate printings (Hrushevs'kyi, Etnohrafichni katehorii; Zvychaina skhema). Even in general, the absence of "high-brow" nonfiction directed at an educated public is noteworthy. It is possible that in the beginning of the twentieth century, censors viewed it more severely than literature aimed at the common people. If this is true, the main weight of restrictions switched with time; originally, they were enacted mainly to prevent common people's access to Ukrainian literature.

The books that were published despite the Valuev Directive, the Ems

25 Kulish's two works were originally published in 1861: Khmel'nyshchyna, both as a separate book and in the journal Osnova, Vyhovshchyna only in Osnova.

${ }^{26}$ Submission of the St. Petersburg Censorship Committee to Main Administration of Press, 7 January 1900, with the decision of the Director of Main Administration of Press. A primer is rejected; submission of St. Petersburg Censorship Committee to Main Administration of Press, 1 February 1902, with the decision of the Director of Main Administration of Press. A. Molodchenko's manuscript Veselka (Rainbow) is rejected, since it is a textbook for children; submission of St. Petersburg Censorship Committee to Main Administration of Press, 30 September 1902, with the decision of the Director of Main Administration of Press. An additional children's textbook is rejected.

27 Odesa censor to Main Administration of Press, 15 April 1898, a publisher Il'ia Shrakh to Main Administration of Press, 18 November 1898.

28 St. Petersburg Censorship Committee's decision, 3 September 1902; Bilenky. Fabrikant informs about this ban, but he is wrong when claiming that this book was permitted only in Russian translation, for it was printed in 1863, 1871, 1874, and 1882. 
Ukaz, and other restrictions against Ukrainian literature were not mere anomalies, but formed a substantial part of Ukrainian literature published in 1863-1904. The first period of many such exceptions, 1874-76, is explained by the difficulty of the central imperial government to get its policies enforced in the provinces. However, the later periods with many exceptions, 1882-83 and 1896-1904, demonstrate vacillation in the central bodies of censorship, which deviated from the explicit rules. In each period, Ukrainian national activists quickly began to use the new opportunities available. While the granted exceptions were substantial, it is good to keep in mind that deviations also occurred in the other direction: books that were not banned according to the letter of the Ems Ukaz were rejected by the censors. Because of the importance of exceptions, analysis of censorship of Ukrainian literature cannot be based only on the texts of the Valuev Directive, Ems Ukaz, and other normative restrictive regulations on Ukrainian publications. In order to understand the censorship, we have to study how it functioned in practice in individual cases.

\section{Works Cited}

(Beliaiev), V. H. "Zhyttia i tvorchist' Danyla Mordovtsia," in Danylo Mordovets', Tvory. 2 vols., Derzhavne vydavnytstvo khudozhn'oi literatury, 1958, vol. 1, pp. 5-38.

Boriak, Hennadiy, editor. Ukrains'ka identychnist'i movne pytannia v Rosiis'kii imperii: Sproba derzhavnoho rehuliuvannia (1847-1914). Zbirnyk dokumentiv i materialiv. Instytut istorii Ukrainy NAN Ukrainy, 2013.

Chaichenko, V. (Borys Hrinchenko). Pro hrim ta blyskavku. Kharkiv, 1883.

Chykalenko, Ievhen. Rozmovy pro sel's'ke khoziaistvo. Odesa, 1897.

De-shcho pro svit Bozhyi. 2nd ed., Kyiv, 1863.

De-shcho pro svit Bozhyi. 3rd ed., Ades [Odesa], 1874.

De shcho pro svit Bozhyi. 4th ed., Kyiv, 1882.

Drahomanov, Mykhailo. Vybrane. Lybid', 1991.

Horbunov, N. Shcho robyt'sia u vozdusi $i$ shcho z toho treba znaty zemlerobu. Translated from Russian into Ukrainian by I.M.R., Kyiv, 1875.

Hrushevs'kyi, Mykhailo. Etnohrafichni katehorii i kul'turno-arkheolohichni typy v suchasnykh studiiakh Skhidnoi Ievropy. Tipografiia Imperatorskoi Akademii Nauk, 1904.

---. Zvychaina skhema "russkoi" istorii i sprava ratsional'noho ukladu istorii skhidnoho slav"ianstva. Tipografiia Imperatorskoi Akademii Nauk, 1904.

Iastrubets' (Fedir Vovk). Pro zviriv (po bremu). Mniasoidy abo khyzhi zviri 1. Vedmedi. Kyiv, 1876.

Ivanov, A. Rozmova pro nebo ta zemliu: $Z$ deiakymy odminamy $i$ dodatkamy. Translated from Russian into Ukrainian by M. Komarov, Kyiv, 1874.

--- Rozmova pro zemni syly A. Ivanova. $Z$ deiakymy dodatkamy ta odminamy. Translated from Russian into Ukrainian by M. Komarov, Kyiv, 1875.

Khutornyi, T. (T. H. Lubenets'). Chytanka: Persha knyzhka pislia hramatky: Z 60 
maliunkamy. Kyiv, 1883.

Khvidorovs'kyi, M. F. Pro dyfteryt abo obkladky dlia selian i khutorian na Ukraini. Kharkiv, 1882.

Komar, M. (Komarov, Mykhailo). Byblyohrafychnyi pokazhchyk novoi ukrains'koi literatury (1798-1883 r.). Kyiv, 1883.

---. Opovidannia pro Antona Holovatoho ta pro pochatok chornomors'koho kozats'koho viis'ka. Blagotvoritel'noe obshchestvo izdaniia obshchepoleznykh i deshevykh knig, 1901.

---. Opovidannia pro Bohdana Khmel'nyts'koho: Iak vyzvolyv vin Ukrainu od nevoli pol's'koi. Blagotvoritel'noe obshchestvo izdaniia obshchepoleznykh i deshevykh knig, 1901.

Konys'kyi, Oleksandr (0. K.). Hramatka abo persha chytanka za dlia pochatku vchen'ia. Kyiv, 1882.

---. Opovidannia pro Tarasa Shevchenka. Blagotvoritel'noe obshchestvo izdaniia obshchepoleznykh i deshevykh knig, 1901.

Kulish, Panteleimon. Khmel'nyshchyna: Istorychne opovidannia. 2nd ed., Tipografiia P. Barskogo, 1901.

---. Vyhovshchyna: Istorychne opovidannia. Z portretom Vyhovs'koho. Blagotvoritel'noe obshchestvo izdaniia obshchepoleznykh i deshevykh knig, 1901.

Levchenko, Mikhail. Opyt russko-ukrainskogo slovaria. Kyiv, 1874.

Levyts'kyi, Ivan. Pershi kyivs'ki kniazi Oleh, Ihor, Sviatoslav i sviatyi Volodymyr i ioho potomky. Kyiv, 1876.

---. Tatary i Lytva na Ukraini. Kyiv, 1876.

---. Uniia i Petro Mohyla—kyivs'kyi mytropolyt. Kyiv, 1875.

Miller, Aleksei I. The Ukrainian Question: The Russian Empire and Nationalism in the Nineteenth Century. Translated from Russian by Olga Poato. Central European University Press, 2003.

Nakhlik, Ievhen. Panteleimon Kulish: Osobystist', pys'mennyk, myslytel'. Naukova monohrafiia. 2 vols., Ukrains'kyi pys'mennyk, 2007.

Nis, Stepan [anonymously]. Liky svoienarodni, z domashnieho obikhodu i v kartynakh zhyttia. Kyiv, 1875.

--- [anonymously]. Pro kholeru. Kyiv, 1875.

--- [anonymously]. Pro khvoroby i iak im zapomohty. Kyiv, 1874.

Omel'chuk, V. Iu., et al, editors. Ukrainomovna knyha, 1798-1916. 4 vols., Abrys, 19962002.

Opatovych, Stefan. Opovidania z sviatoho pysannia. 2nd ed., Kyiv 1875.

Pro hroshi. Translated from Russian into Ukrainian by Vikhtur Shcherbatyi (pseudonym), Kyiv, 1874.

Pro kary, do iakykh prysudzhaiut' myrovi suddi. Kyiv, 1876.

Remy, Johannes. "The Valuev Circular and Censorship of Ukrainian Publications in the Russian Empire (1863-76): Intention and Practice." Canadian Slavonic Papers, vol. 49, no. 1-2, 2007, pp. 87-110.

Rodkiewicz, Witold. Russian Nationality Policy in the Western Provinces of the Empire (1863-1905). Scientific Society of Lublin, 1998.

Rossiiskii gosudarstvennyi istoricheskii arkhiv (RGIA). Fond 776, Opis' 11, 1872 God., Delo 80. O sluzhbe st. sov. Puzyrevskogo. 
Ryl's'kyi, Tadei [anonymously]. Pro khersons'ki zarobitky, koly i iak ikh shukaty, $i$ shcho koshtuie tudy dostat'sia po zaliznii dorozi abo parokhodom. Kyiv, 1899.

Saunders, David. "The Russian Imperial Authorities and Yevhen Chykalenko's Rozmovy pro sel's'ke khoziaistvo." Journal of Ukrainian Studies, vol. 33/34, Summer 2008-Winter 2009, pp. 417-28.

---. "Russia's Ukrainian Policy (1847-1905): A Demographic Approach." European History Quarterly, vol. 25, no. 2, April 1995, pp. 181-208.

Stepovyk, O. (O. F. Komarov). Korystni zviriatka: Kazhan, iizhak ta zins'ke shchenia (krit). St. Petersburg, 1899.

---. Opovidannia pro komakh: Iaka od ikh koryst' abo shkoda v hospodarstvi (z 45 maliunkamy). Kyiv, 1882.

Slipchenko-Mordovets', Danylo. Za krashanku - pysanka P. Ol. Kulishevi. St. Petersburg, 1882.

Trots'kyi, Mykola. Iak teper odbuvatymet'sia voienna sluzhba. Kyiv, 1874.

Vahanov, S. Berezhenoho Boh berezhe: Opovydan'ia selianyna pro skots'ku chumu. Iekaterynodar, 1896.

Zahyrnia, M. (Mariia Hrinchenko). Iak vyhadano mashynoiu izdyty. Chernihiv, 1896.

---. Orleans'ka divchyna Zhanna D'Ark. Chernihiv, 1897. 